\title{
Growth of escarole in different seasons of year, RS, Brazil
}

\section{Crescimento de chicória em diferentes estações do ano, RS, Brasil}

\author{
Daniele Cristina Fontana ${ }^{1 *}$; Braulio Otomar Caron²; Denise Schmidt ${ }^{2}$; \\ Daniela Meira ${ }^{1}$; Thais Pollon Zanatta ${ }^{1}$; Patricia Brezolin ${ }^{3}$; Carla Janaina Werner ${ }^{3}$
}

\begin{abstract}
The lack of research about escarole cultivars adapted to each region, as well as technical information on plant growth have been some of the factors related to low yields. Therefore, the aim of this work was to evaluate the growth of escarole crop in four seasons of year in Santa Maria, RS. The experiment was conducted in a randomized complete block design, 1 x 4, being a escarole (cultivar Escorola Lisa ${ }^{\circledR}$ ) evaluated in four seasons of year (summer, autumn, winter and spring), in six replications. The evaluations were performed in a destructive manner every seven days, from date of transplant to harvest point. The following components were analyzed: number of leaves, number of residues, dry mass of leaves, dry mass of leaves, stem and residue. Thus, it was determined the parameters for growth analysis. With the data obtained, we performed a variance analysis, and presented significant results, and the means of each season of the year submitted to the Tukey test at $5 \%$ of error probability. The air temperature and global radiation influence crop cycle. Lower temperatures and lower incidence of radiation result in cycle extended, as observed in autumn. The escarole growth is influenced by seasons of year in Rio Grande do Sul (RS), and summer and spring finish the cycle in advance to others, presenting a larger leaf area. Summer and spring are most indicated season to escarole crop in RS, Brazil.
\end{abstract}

Key words: Chicorium endivia. Spring. Summer.

\section{Resumo}

A falta de pesquisas sobre cultivares de chicória adaptadas a cada região, bem como informações técnicas sobre seu crescimento, tem sido alguns dos fatores relacionados a baixos rendimentos. Diante disso, o objetivo deste trabalho foi avaliar o crescimento da cultura da Chicória em quatro estações do ano em Santa Maria- RS. O experimento foi conduzido em delineamento de blocos ao acaso, 1 x 4, sendo uma cultivar de chicória (cultivar Escorola Lisa ${ }^{\circledR}$ ) avaliada em quatro estações do ano (verão, outono, inverno e primavera), com seis repetições. As avaliações foram realizadas de forma destrutiva a cada sete dias, a partir da data do transplantio até o ponto de colheita. Analisaram-se os seguintes componentes: número de folhas, número de restos, massa seca de discos, massa seca de folhas, caule e restos. Com os dados obtidos procedeu-se análise de variância, e apresentando resultados significativos, e as médias de cada estação do ano submetidas ao teste de Tukey a 5\% de probabilidade de erro. A temperatura do ar e a radiação global apresentaram influência sobre o ciclo da cultura. Temperaturas mais baixas e menor incidência de radiação resultaram no maior ciclo da cultura, observado no outono.

${ }^{1}$ Eng $^{\text {os }}$ Agros, Discentes do curso de Mestrado, Programa de Pós-Graduação em Agronomia, Agricultura e Ambiente, Universidade Federal de Santa Maria, Campus Frederico Westphalen, UFSM, Frederico Westphalen, RS, Brasil. E-mail: daani_fontana@, hotmail.com; danielameira19@hotmail.com; thais_2zanatta@hotmail.com

${ }^{2}$ Eng $^{\text {os }}$ Agr $^{o s}$, Profs. Drs. Associado, Campus Frederico Westphalen, UFSM, Frederico Westphalen, RS, Brasil. E-mail: otomarcaron@yahoo.com.br; denise@ufsm.br

${ }^{3}$ Eng $^{\text {os }}$ Agr ${ }^{\text {os }}$, Campus Frederico Westphalen, UFSM, Frederico Westphalen, RS, Brasil. E-mail: patriciabrezolin@hotmail.com; carli.werner@hotmail.com

* Author for correspondence 
O crescimento da chicória foi influenciado pelas estações do ano no Rio Grande do Sul (RS), sendo que o verão e primavera finalizaram o ciclo antecipadamente às demais, apresentando maior área foliar. Verão e primavera são as estações mais indicadas para o cultivo da chicória no RS, Brasil.

Palavras-chave: Chicorium endivia. Primavera. Verão.

\section{Introduction}

The escarole (Cichorium endivia L.) is a leafy vegetable, belonging to the family Asteraceae. It presents similarity to lettuce crop, however, its curly or smooth leaves do not form head (KANDELER; ULLRICH, 2009).

Among the factors related to the low yields, we highlight a lack of research on cultivars adapted to the regions, as well as technical information about growth of this plant (GRANGEIRO et al., 2006). Therefore, the growth analysis is widely used to follow the growth standard of the plant or parts of it, allowing to infer the contribution of different physiological processes to growth and development of plants, being useful in studying the interference of environmental conditions, how was verified in research with physalis (PEDÓ et al., 2013) and tomato (MARTINAZZO et al., 2015). In this case, meteorological conditions that may influence the different stages of crops (BRAGANÇA et al., 2010; CARON et al., 2007).

The adaptation of materials to various microclimates is among the greatest difficulties found for growth and development of plants (PEREIRA; LOPES, 2011). In this regard, Beckmann-Cavalcante et al. (2009) cite that air temperature is a main variable that affects a plant growth rate. For lettuce, belonging to the same botanical family of escarola, several studies have been carried out to evaluate the performance of cultivars in different regions of Brazil (SANTANA et al., 2012).

However, little is known about the growth of escarole (Cichorium endivia L.), many factors affect yield and quality of the final product, causing frustration to producers. In this way, the aim of this work was to evaluate the growth of escarole in four seasons of the year, in the northwest region of Rio Grande do Sul.

\section{Material and Methods}

\section{Plant Material and experiment conditions}

The work was developed in FredericoWestphalen - RS, and the experimental area is located at coordinates $27^{\circ} 39^{\prime} \mathrm{S}$ and $53^{\circ} 42^{\prime} \mathrm{O}$, with an altitude of 490 meters. The region climate is classified as subtropical humid with average annual temperature of $19.1^{\circ} \mathrm{C}$ and average annual precipitation of 1880 $\mathrm{mm}$. The soil of the experimental area is classified as Dystrophic Red Latosol (SANTOS et al., 2006).

The experiment was conducted in a randomized block design, using escarole (Cichorium endivia L.) Escarola Lisa ${ }^{\circledR}$ cultivar, and it was cultivated in four seasons, summer, autumn winter and spring the of the year in the northern state of Rio Grande do Sul. Each season was composed of six replicates, each plant being an experimental unit.

The growing schedule is described in Table 1, with seasons 1 to 4 representing summer, autumn, winter and spring, respectively. The beds were carried out with plowing and sorting, and the fertilization proceeded according to the interpretation of soil analysis, according to the Manual of Fertilization and Liming for Comissão de Química e fertilidade do solo-CQFSRS/RS (2004). The growth was carried out in beds of $1.2 \mathrm{~m}$ wide and the plants arranged in a spacing of $0.20 \times 0.25 \mathrm{~m}$.

The reference evapotranspiration was calculated according to Penman (1948) and adapted by Monteith (1965). The daily water requirement calculated by the multiplication of the ETo to crop coefficient (Kc) (ALLEN et al., 1998), being an irrigation available through the drip system. 
Table 1. Seeding, transplant and harvest date of escarole for each growing season. FredericoWestphalen - RS.

\begin{tabular}{cccc}
\hline Growing Season & Seeding Date & Transplant Date & Harvest Date \\
\hline 1 & $01 / 19 / 2015$ & $02 / 03 / 2015$ & $03 / 31 / 2015$ \\
2 & $03 / 28 / 2015$ & $04 / 22 / 2015$ & $06 / 29 / 2015$ \\
3 & $06 / 25 / 2015$ & $07 / 22 / 2015$ & $09 / 16 / 2015$ \\
4 & $09 / 25 / 2015$ & $10 / 16 / 2015$ & $12 / 16 / 2015$ \\
\hline
\end{tabular}

\section{Growth analysis}

The growth analysis was performed destructive manner every seven days, from the date of transplant to harvest point, which was established when the plants reached a larger leaf area and in the previous period the beginning of floral stem elongation, varying according to season (Table 1).

For the evaluations, the following components were analyzed: number of leaves (leaves $>5 \mathrm{~cm}$ ), number of residues (leaves $<5 \mathrm{~cm}$ ), dry mass of disks $\left(\mathrm{g} \mathrm{plant}^{-1}\right)$, dry mass of leaves, stem and residues $\left(\mathrm{g} \mathrm{plant}^{-1}\right)$. To determine the dry mass, the samples were packed in paper bag and transferred to drying oven at $72^{\circ} \mathrm{C}$, until reaching constant weight, and then weighed on a precision balance.

According to the results of the above components mentioned, the parameters for the growth analysis were determined: leaf area index (LAI), leaf area ratio (LAR), specific leaf area (SLA), leaf weight ratio (LWR), biological productivity (BP), relative growth rate (RGR), absolute growth rate (AGR), net assimilation rate (NAR) according to Benincasa (2004).

\section{Statistical analysis}

The data obtained were analyzed by the statistical program Genes (CRUZ, 2013). We performed a variance analysis, and presented significant results, the means of each season of the year submitted to the Tukey test $(\mathrm{p}<0.05)$. The Microsoft Office Excel ${ }^{\circledR}$ program (WALKENBACH, 2010) was used to prepare the graphs.

\section{Results and Discussion}

Figures 1 and 2 show the meteorological data collected from the Frederico Westphalen - RS automatic weather station during the growing season. The air temperature is an important variable to be analyzed, in the year 2015, the temperatures recorded demonstrated an atypical year, without the well defined seasons described, according to Koppen. The lowest maximum and minimum temperatures were recorded in May and June, reaching values of $4^{\circ} \mathrm{C}$ and $33.7^{\circ} \mathrm{C}$, respectively. The precipitation levels were not regular, because in January, July, November and December the highest rainfall indexes were recorded, both above $350 \mathrm{~mm}$ (Figure 1).

The statistical analysis showed significance for the F test for leaf area index (LAI), leaf area ratio (LAR), specific leaf area (SLA), foliar weight ratio (FWR), relative growth rate (RGR), absolute growth rate (AGR), net assimilation rate (NAR), and therefore a comparison of averages was made by Tukey test, at $5 \%$ probability of error, among the seasons of the year, presented in Figures 3, 4, 5 and 6. 
Figure 1. Meteorological data of daily precipitation, maximum and minimum temperatures, and evapotranspiration during escarole crop (Cichorium endivia L.) Escarola Lisa ${ }^{\circledR}$ cultivar.

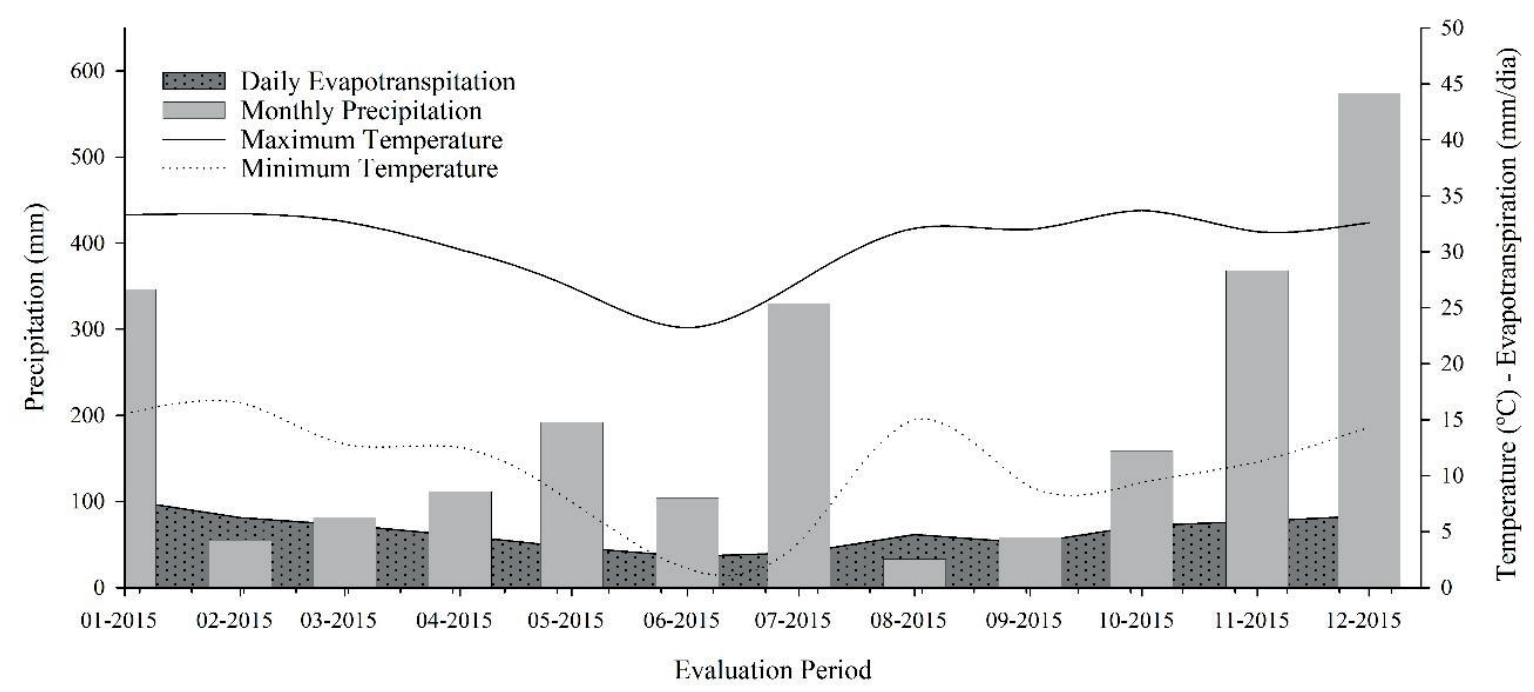

Source: INMET, (Frederico Westphalen - A854) Frederico Westphalen - RS automatic weather station.

Figure 2. Meteorological data of maximum and minimum daily air relative humidity and global radiation during escarole crop (Cichorium endivia L.) Escarola Lisa ${ }^{\circledR}$ cultivar.

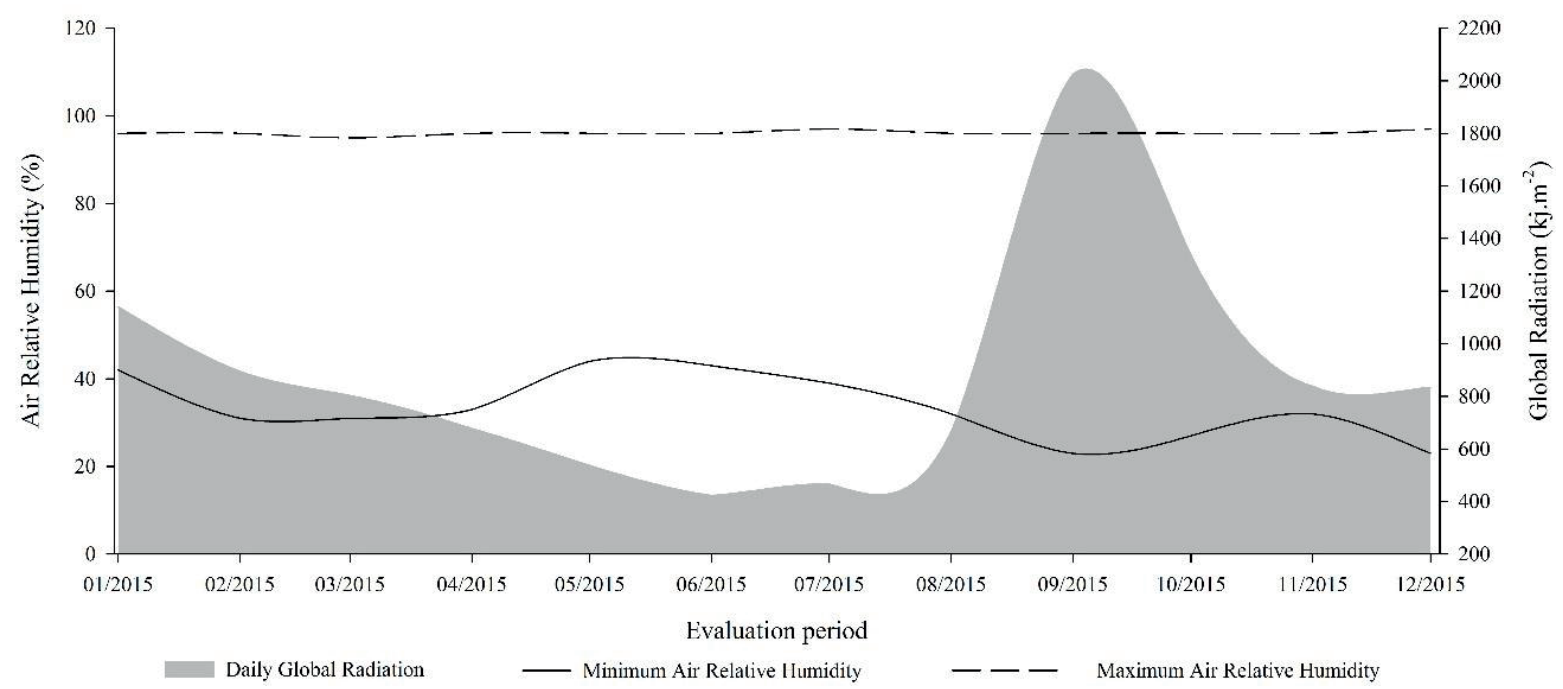

Source: INMET, (Frederico Westphalen - A854) Frederico Westphalen - RS automatic weather station.

The leaf area index (LAI) increased during the evaluations, indicating that the constant emission of new leaves and/or their expansion was superior to senescence process. Only from the fifth evaluation were growing seasons significantly different for LAI, with seasons 1 and 3 showing the highest indices until harvest point, occurring one week before the other seasons (Figure 3-A). The growing seasons only differed when the plants, after being adapted, began the translocation of photoassimilates, and the auto-shading of the leaves happened, passing to a phase of linear growth, with greater increase in 
the dry matter rate. These results corroborate with research carried out by Peixoto and Peixoto (2004).

During growing seasons, in seasons 1 and 3, minimum and maximum temperatures were observed between 10 and $15^{\circ} \mathrm{C}$, and 25 and $33^{\circ} \mathrm{C}$, respectively. Temperatures below $8^{\circ} \mathrm{C}$ soon after transplanting increase escarole cycle, however, temperatures above $40^{\circ} \mathrm{C}$ negatively affect to crop
(SÁ; REGHIN, 2008), because acceleration in metabolism results in less accumulation by plants. From this aspect, it can be inferred that the average temperatures observed at these seasons may have been adequate to provide plants with greater photosynthetic area, and consequently greater photoassimilated production and translocation, resulting in greater growth and development (ZUFFO et al., 2016), ending the cycle more quickly.

Figure 3. Leaf area index (A), leaf area ratio (B), for the four growing seasons (summer, autumn, winter and spring) of escarole in 2015. Frederico Westphalen - RS.

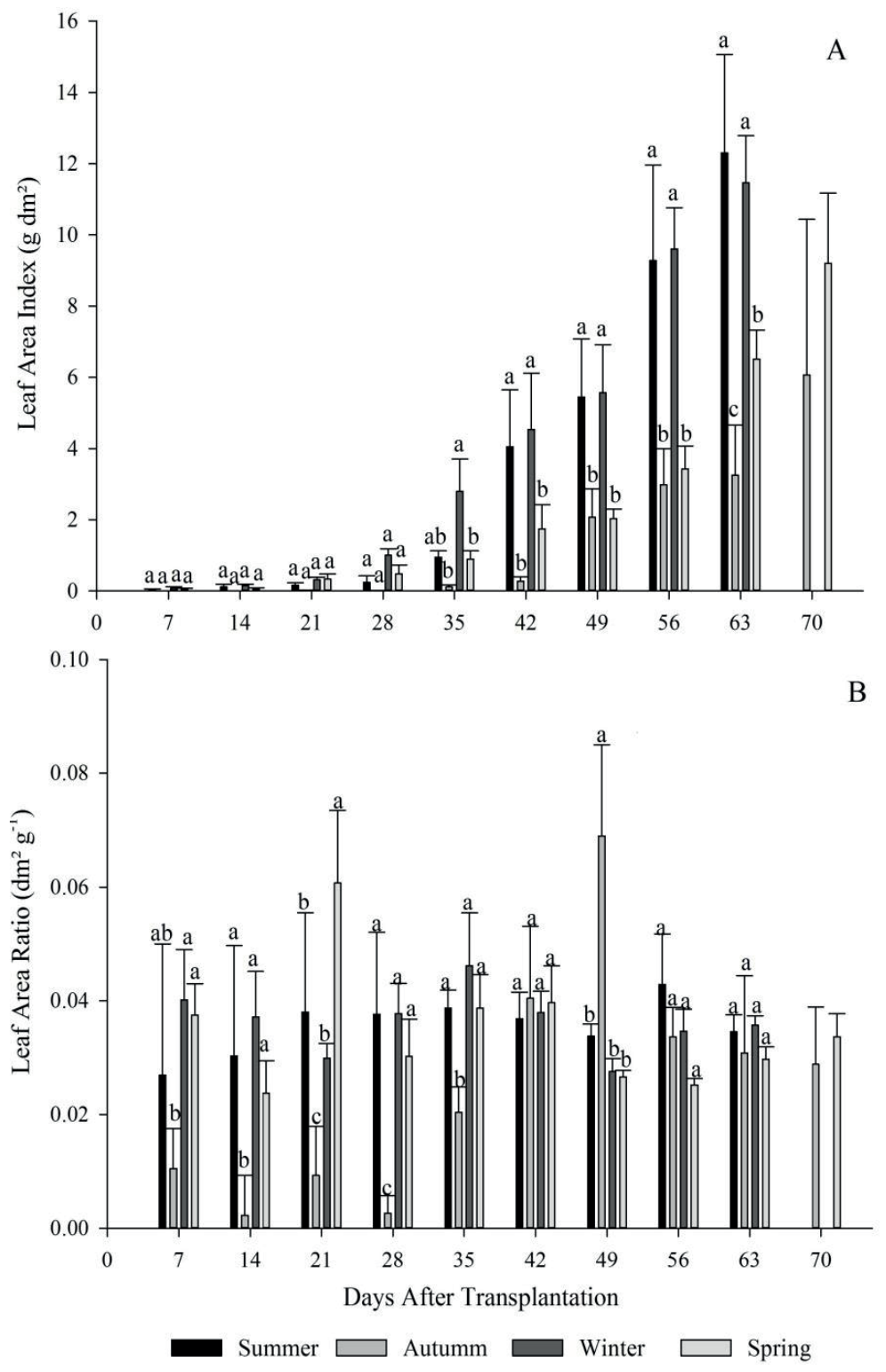

*Averages followed by the same lowercase letters do not differ statistically by the Tukey test at $5 \%$ error probability. 
The low LAI at beginning crop cycle for all seasons is due to the great energy spent of plants for their fixation to the soil and their initial adaptation (REIS et al., 2013). For some crops, the highest leaf area index occurs in the first stages of growth, decreasing the useful leaf area during the cycle (BENINCASA, 2003).

Leaf area ratio (LAR) was superior in seasons 1, 3 and 4 at 7, 14, 28 and 35 days after transplant (DAT), compared to season 2. However, only at 49 days after transplanting the season 2 was statistically superior to the other seasons (Figure 3 - B). The lowest LAR verified in season 2 to 35 DAT shows the acclimatization of crop to the environmental conditions, because in this season the lowest temperatures of the year were observed, reaching $4{ }^{\circ} \mathrm{C}$. As well air temperature, as soil and surface leaves temperature, affect directly the speed of chemical reactions, internal solutes transport processes and the normal plants development, being that the low temperatures reduce the conversion efficiency of physiological processes occurred, resulting in low RAF.

At 21 days after transplanting, season 4 was statistically superior to seasons 2 and 3 for the specific leaf area (SLA). In the evaluation performed at 28 DAT, it was observed that season 2 had the lowest indexes, however, its inverse relation was verified at 49 DAT, presenting a significant difference to the other growing seasons (Figure 4-A). The increase of LAR and SLA at 49 DAT in season 2 is due to the accumulation of photoassimilates occurred until this stage, due to the low energy cost for respiration and also due to plants population presenting smaller amounts of carbohydrates to be assimilated, resulting in high photosynthetic efficiency during this week.

Other factors that may have influenced the superiority of LAR and SLA from season 2 at 49
DAT are linked to the low LAI of the period, coupled with low solar radiation and high relative humidity, affecting directly the increase of leaf area. The plants that are submitted to low levels of radiation present low efficiency in the interception of solar energy, proportionally reducing the photosynthetic level and the production of substrates, consequently lower increment of dry matter for plant growth. It is also worth noting, that only about $44 \%$ of incident solar radiation arriving at wavelengths that can be used by the plant (CUNHA; VOLPE, 2010).

The radiation use is influenced by cultures and their growth and development conditions (FONTANA et al., 2012), as well as by the seasons of the year and cultural management to which they are subjected. The tendency of plants, under low light conditions is to increase the leaf area to improve the absortion of the low light present in these conditions (PACIULLO et al., 2007). Thus, it is justified that not all incident radiation will result in phytomass increase, since the conversion efficiency is greatly influenced by the environmental conditions.

The similarity verified near the point of harvest, in both seasons, demonstrates that plants, despite the conditions to which they were submitted, were able to carry out their vital processes completing the cycle.

For leaf weight ratio (LWR), season 2 also presented the lowest indexes, differing significantly from the other seasons until the 21 DAT. After, all the seasons showed similar behavior until harvest point, being the averages of seasons 1 to 4 : 0,818 ; $0.920 ; 0.879$ and $0.751 \mathrm{~g} \mathrm{~g}^{-1}$ day, respectively (Figure 4-B). For Digitaria insularis, Machado et al. (2006) found an average of $0.74 \mathrm{~g} \mathrm{~g}^{-1}$. This reason shows that until 21 days in the autumn, escarole plants present a small increment of leaf area, providing a low export of photoassimilates from the leaves to the plant drains. 
Figure 4. Specific leaf area (A) and leaf weight ratio (B) for the four growing seasons (summer, autumn, winter and spring) of escarole in 2015. Frederico Westphalen - RS.
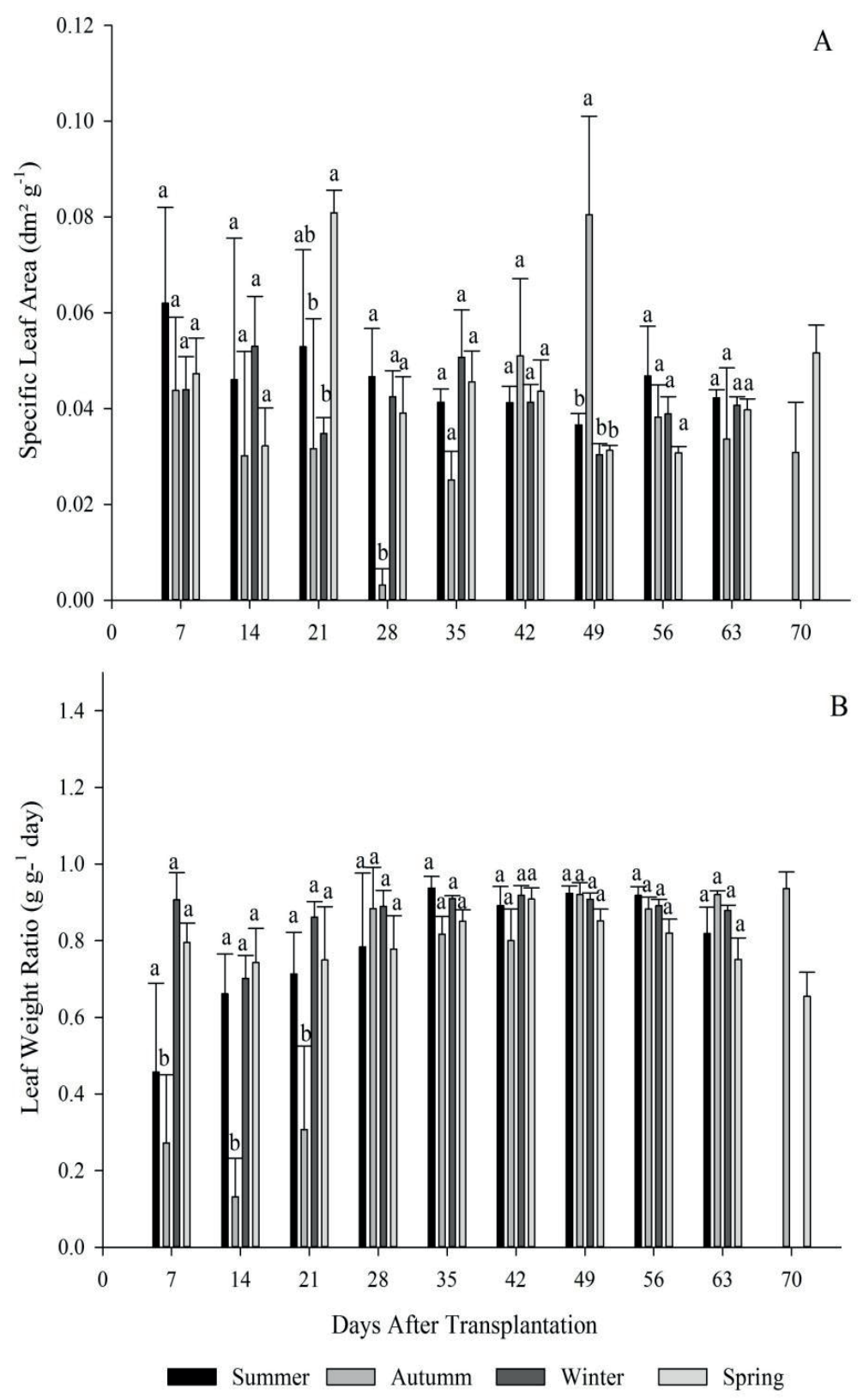

*Averages followed by the same lowercase letters do not differ statistically by the Tukey test at $5 \%$ error probability.

The results found for LWR indicate the highest allocation of photosynthesized products to the organs of interest (MACHADO et al., 2006), and for escarole there is an increase of the pseudostem, justifying the reduction of the NAR.

For the biological productivity (BP) it is possible to observe at 28 DAT in the seasons 3 and 4 were statistically superior, and at 35, 42, 49 and 56 DAT, only the season 3 stood out from the others. Seasons 1 and 3 were significantly higher at 63 DAT, ending their cycle, and the lowest averages of BP were observed for season 2 again (Figure $5-\mathrm{A}$ ). 
The low values of seasons 2 and 4 are linked to the low LAI of growth conditions. Therefore, it is observed that meteorological conditions verified did not condition high photosynthetic rates, providing smaller leaf area, lower accumulation of dry matter and consequently lower growth, extending the crop cycle, which is not desired.

Figure 5. Biological productivity (A), absolute growth rate (B) for four growing seasons (summer, autumn, winter and spring) of escarole in 2015. Frederico Westphalen - RS.
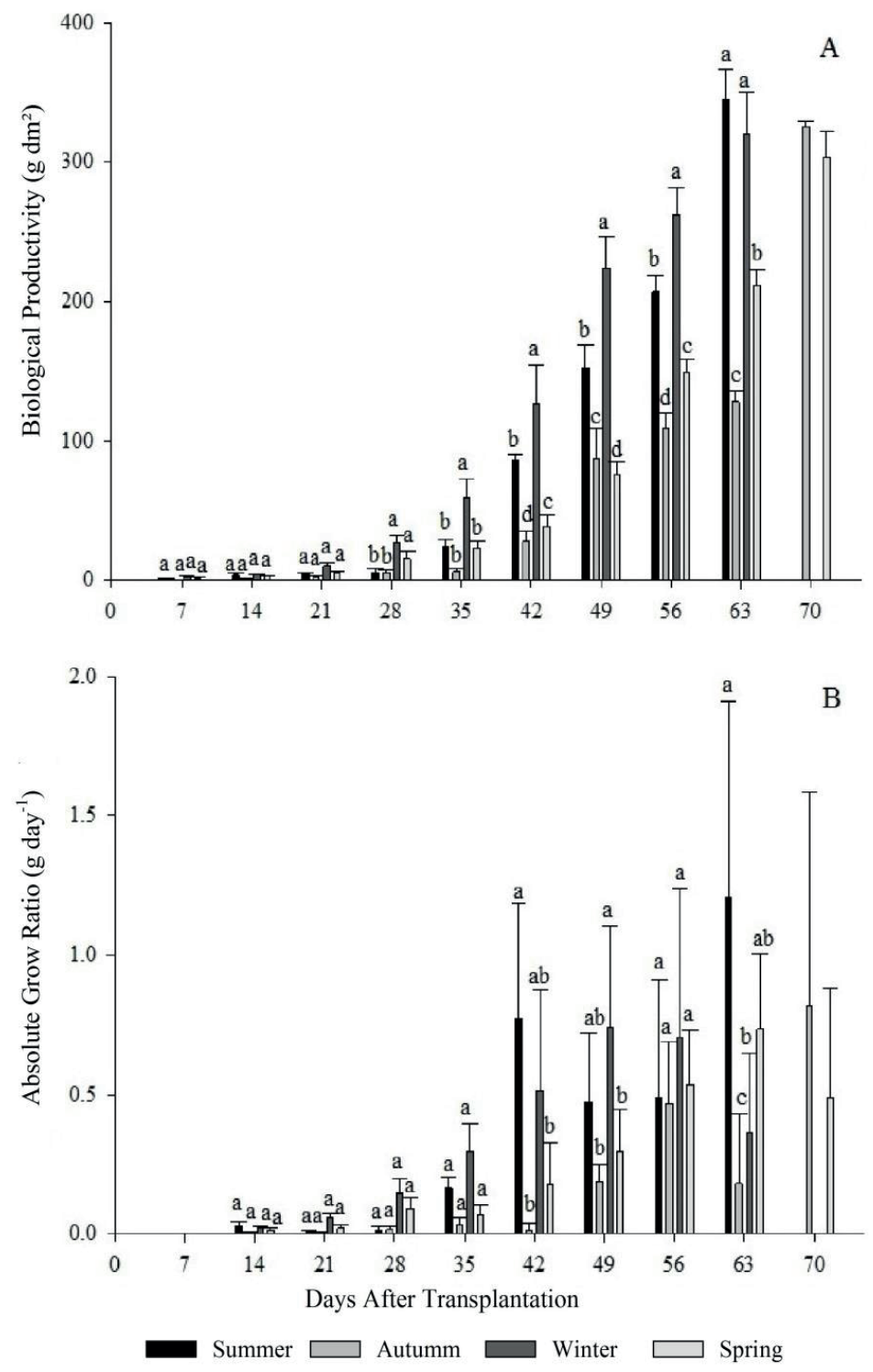

*Averages followed by the same lowercase letters do not differ statistically by the Tukey test at $5 \%$ error probability.

It is also known, that high temperatures influence the stomatal conductance, increase the metabolic activity of the tissues and increase the degradation of the cells, increasing the rate of respiration.
Thus, for some, the increase in the respiration rate is concomitant with the increase in the relative growth rate (BEEVERS, 1970). However, for other plants, the relation is inversely related. This 
fact can be explained by the different composition of the phytomass formed, which will require different energy requirements for the synthesis of its compounds (PENNING de VRIES, 1973).

The meteorological variables such as temperature and solar radiation are strictly linked, and when their values are reduced, plant growth decreases, but when they are high, they can be harmful to synthesis of plant compounds and cause damage. Therefore, the definition of an optimal ecological condition is difficult, since several factors can affect great plant development.

Figure $6-\mathrm{B}$ shows that BP is inversely proportional to the photosynthetic rate, so are justifiable the high NAR values for seasons 2 and 4 , at end and beginning of the cycle, respectively.

Figure 6. Relative growth rate (A), net assimilation rate (B) for four growing seasons (summer, autumn, winter and spring) of escarole in 2015. Frederico Westphalen - RS.
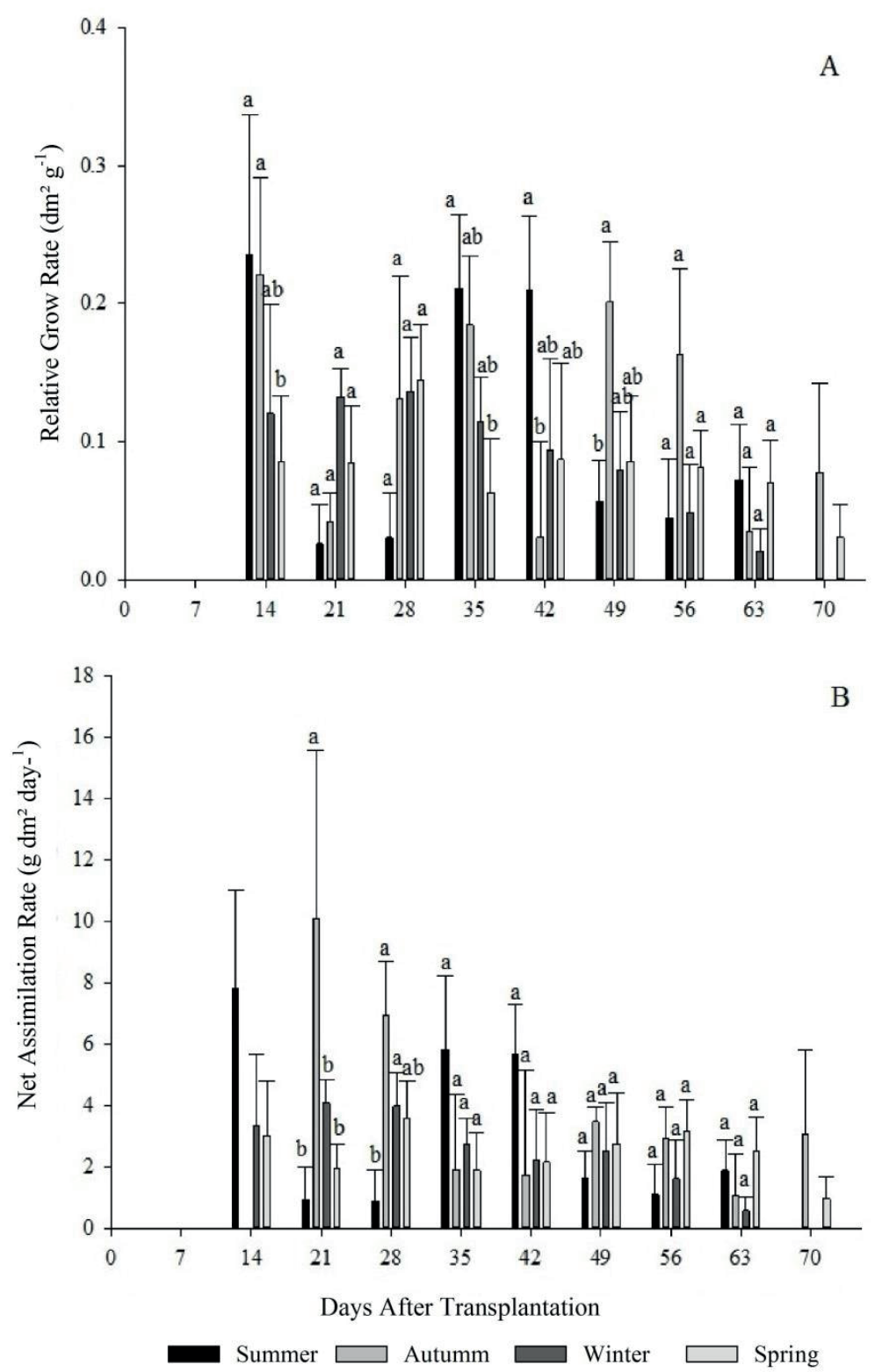

*Averages followed by the same lowercase letters do not differ statistically by the Tukey test at $5 \%$ error probability. 
In the self-shading occurs NAR reduction, since the radiation intercept flow is distributed heterogeneously on the surface leaves (PETTER et al., 2016), which is reduced more drastically in low radiation conditions, requiring that plants are more efficient in their energy processes.

For the absolute growth rate (AGR), significant difference was observed, and only the evaluations at 42, 49 and 63 showed differences between the growing seasons. At 42 DAT in season 1 presented $0.77 \mathrm{~g}$ day $^{-1}$ of AGR, and maximum and minimum temperatures of $33.4^{\circ} \mathrm{C}$ and $12.8^{\circ} \mathrm{C}$, respectively. At 49 DAT, season 3 presented an AGR of $0.74 \mathrm{~g} \mathrm{day}^{-1}$. However, growing season 1 presented the highest values with $1.21 \mathrm{~g} \mathrm{day}^{-1}$ at $63 \mathrm{DAT}$, demonstrating the occurrence of higher dry matter increase in this period (56-63 DAT), also providing seasons 1 and 3 reaching harvest point. Season 2 presented the lowest values of AGR in all evaluations performed (Figure $5-\mathrm{B}$ ).

The increase of dry matter during the cycle demonstrates the energy conversion efficiency in the plant, because with a greater photosynthetic area the plant produces more photoassimilates, which translocates more quickly to its drains.

In an experiment with lettuce, Caron et al. (2003) verified AGR of $0.19 \mathrm{~g} \mathrm{day}^{-1}$, under temperature conditions of 25.3 and $8.4^{\circ} \mathrm{C}$. The low plant growth velocity in season 2 , in the present study, is justified by the low values found by AGR, and the high incremental efficiency observed in season 1 may be associated with high temperatures.

For the relative growth rate (RGR) (Figure 6-A), there was a variance between the growing seasons of the year, and season 1 and 2 were higher at 14 DAT, differing statistically from season 4 . At 35 and 42 DAT, season 2 and 1, respectively, stood out from the others presenting the highest rates. However, at 49 DAT in season 2 presented significant increase in the rate, differing from the others.

The observed significance for the RGR in growing season, corresponding to autumn, differs for AGR, BP, LWR, LAR and LAI, which presented the lowest values in season, due to the conditions already discussed. The RGR variation is due to two growth factors: LAR and NAR, that is, a leaf area useful for photosynthesis and a net assimilation rate.

RGR and NAR are associated, and this rate decreases with time, due to the increase of need for carbohydrate assimilation in the organs of interest plants, and the need for photoassimilates to maintenance of already formed structures. Thus, the amount of photoassimilates available for growth tends to be lower and, consequently, the RGR decreases with time (PETTER et al., 2016).

For the net assimilation rate (NAR), season 2 presented superiority to $21 \mathrm{DAT}$, however, at 28 days, as well season 2 as 3 were statistically superior to season 1 (Figure $6-\mathrm{B}$ ). It can be observed a decrease in NAR, during the evaluation periods, with the highest rate being verified at the beginning of escarole development. This fact is related to the lower self-shading of crop at beginning plant development, compared to end cycle (GONDIM et al., 2008). The NAR, however, tends to decrease as the LAI increases, an inverse relationship explained as a consequence of plant community growth and leaf senescence.

\section{Conclusion}

The escarole growth is influenced by seasons of year in Northwest Region of Rio Grande do Sul, and the seasons referring to summer and spring finalized the cycle in advance to the others, presenting a larger leaf area. Summer and spring are most indicated season to escarole crop at RS, Brazil.

\section{References}

ALLEN, R. G.; PEREIRA, L. S.; RAES, D.; SMITH, M. Crop evapotranspiration (guidelines for computing crop water requirements) - FAO Irrigation and Drainage Paper 56. FAO, Rome, v. 300, n. 9, p. 1-15, 1998. 
BECKMANN-CAVALCANTE, M. Z.; PIVETTA, K. F. L.; CAVALCANTE, Í. H. L.; CAVALCANTE, L. F.; BELLINGIERI, P. A. Soluções nutritivas no desenvolvimento do Crisântemo cultivado em vaso. Irriga, Botucatu, v. 14, n. 2, p. 205-219, 2009.

BEEVERS, H. Respiration in plants and its regulation. In: SETLIK, L. (Ed.). Prediction and measurement of photosynthetic productivity. Wageningen: Pudoc, 1970. p. 221-230.

BENINCASA, M. M. P. Análise de crescimento de plantas: noções básicas. Jaboticabal: FUNEP, 2003. 41 p.

Análise de crescimento de plantas: noções básicas. 3. ed. Jaboticabal: FUNEP, 2004. 41 p.

BRAGANÇA, S. M.; MARTINEZ, H. E. P.; LEITE, H. G.; SANTOS, L. P.; LANI, J. A.; SEDIYAMA, C. S.; ALVAREZ, V. V. H. Acumulação de matéria seca pelo cafeeiro conilon. Revista Ceres, Viçosa, MG, v. 57, n. 1, p. $48-52,2010$.

CARON, B. O.; MANFRON, P. A.; LÚCIO, A. D.; SCHMIDT, S.; MEDEIROS, S. L.P.;BONNECARRÉRE, R. A. G.; DOURADO NETO, D. Equações de estimativa da fitomassa da parte aérea da alface. Ciência Rural, Santa Maria, v. 37, n. 5, p. 1248-1254, 2007.

CARON, B. O.; MEDEIROS, S. L. P.; MANFRON, P. A.; SCHMIDT, D.; POMMER, S. F.; BIANCHI, C. Influência da temperatura do ar e radiação solar no acúmulo de fitomassa da alface. Revista Brasileira de Agrometeorologia, Santa Maria, v. 11, n. 2, p. 275-283, 2003.

COMISSÃO DE QUÍMICA E FERTILIDADE DO SOLO-CQFSRS/SC. Manual de adubação e calagem para os estados do Rio Grande do Sul e Santa Catarina. 10. ed. Porto Alegre: Sociedade Brasileira de Ciência do Solo/Núcleo Regional Sul. 2004. 400 p.

CRUZ, C. D. GENES - a software package for analysis in experimental statistics and quantitative genetics. Acta Scientiarum, Maringá, v. 35, n. 3, p. 271-276, 2013.

CUNHA, A. R.; VOLPE, C. A. Relações radiométricas no terço superior da copa de cafeeiro. Bragantia, Campinas, v. 69 , n. 2 , p. $263-271,2010$.

FONTANA, D. C.; ALVES, G. M.; ROBERTI, D.; MORAES, O. L. L.; GERHARDT, A. Estimativa da radiação fotossinteticamente ativa absorvida pela cultura da soja através de dados do sensor Modis. Bragantia, Campinas, v. 71, n. 4, p. 563-571, 2012.

GONDIM, A. R. O.; PUIATTI, M.; VENTRELLA, M. C.; CECON, P. R. Plasticidade anatômica da folha de taro cultivado sob diferentes condições de sombreamento. Bragantia, Campinas, v. 67, n. 4, p. 1037-1045, 2008.
GRANGEIRO, L. C.; COSTA, K. R.; MEDEIROS, M. A.; SALVIANO, A. M.; NEGREIROS, M. Z.; BEZERRA NETO, F.; OLIVEIRA, S. L. Acúmulo de nutrientes por três cultivares de alface cultivadas em condições do Semi-Árido. Horticultura Brasileira, Brasília, v. 24, n. 2, p. 190-194, 2006.

KANDELER, R.; ULLRICH, W. R. Symbolism of plants: examples from European- Mediterranean culture presented with biology and history of art. Journal of Experimental Botany, Lancaster, v. 60, n. 9, p. 39733974, 2009.

MACHADO, A. F. L.; FERREIRA, L. R.; FERREIRA, F. A.; FIALHO, C. M. T.; TUFFI SANTOS, L. D.; MACHADO, M. S. Análise de crescimento de Digitaria insularis. Planta Daninha, Viçosa, MG, v. 24, n. 4, p. 641-647, 2006.

MARTINAZZO, E. G.; PERBONI, A. T.; POSSO, D. A.; AUMONDE, T. Z.; BACARIN, M. A. Análise de crescimento e partição de assimilados em plantas de tomateiro cv. Micro-Tom submetidas ao nitrogênio e piraclostrobina. Semina: Ciências Agrárias, Londrina, v. 36, n. 5, p. 3001-3012, 2015.

MONTEITH, J. L. Evaporation and environment. In: SYMPOSIUM OF THE SOCIETY FOR EXPERIMENTAL BIOLOGY, 19., 1965, New York. Anais... New York: The State and Movement of Water in Living Organisms, 1965. p. 205-239.

PACIUllo, D. S. C.; De CARVAlho, C. A. B.; AROEIRA, L. J. M.; MORENZ, M. J. F.; LOPES, F. C. F.; ROSSIELLO, R. O. P. Morfofisiologia e valor nutritive do capim-brachiária sob sombreamento natural e a sol pleno. Pesquisa Agropecuária Brasileira, v. 42, n.4, p. 573-579, 2007.

PEDÓ, T.; AUMONDE, T. Z.; LOPES, N. F.; VILLELA, F. A.; MAUCH, C. R. Análise de crescimento e partição de assimilados em plantas de fisalis submetidas a intervalos de adubação foliar. Semina: Ciências Agrárias, Londrina, v. 34, n. 5, p. 2247-2256, 2013.

PEIXOTO, C. P.; PEIXOTO, M. F. S. P. Dinâmica do crescimento vegetal: princípios básicos. Cruz das Almas: Gráfica e Editora Nova Civilização Ltda, 2004. 296 p.

PENMAN, M. L. Evaporation: an introductory survey. Netherlands Journal of Agricultural Science, Netherlands, v. 4, n. 1, p. 9-29, 1948.

PENNING de VRIES, F. W. T. Substrate utilization and respiration in relation to growth and maintenance in higher plants. Wageningen, 1973. $146 \mathrm{p}$. 
PEREIRA, M. D.; LOPES, J. C. Germinação e desenvolvimento de plântulas de pinhão manso sob condições de estresse hídrico simulado. Semina: Ciências Agrárias, Londrina, v. 32, n. 4, p. 1837-1842, 2011.

PETTER, F. A.; SILVA, J. Á. da; ZUFFO, A. M.; ANDRADE, F. R.; PACHECO, L. P.; ALMEIDA, F. A. de. Elevada densidade de semeadura aumenta a produtividade da soja? Respostas da radiação fotossinteticamente ativa. Bragantia, Campinas, v. 75, n. 2, p. 173-183, 2016.

REIS, L. S.; AZEVEDO, C. A. V.; ALBUQUERQUE, A. W. de; SILVA JUNIOR, J. F. Índice de área foliar e produtividade do tomate sob condições de ambiente protegido. Revista Brasileira de Engenharia Agrícola e Ambiental, Campina Grande, v. 17, n. 4, p. 386-391, 2013.

SÁ, G. D. de; REGHIN, M. Y. Desempenho de duas cultivares de chicória em três ambientes de cultivo. Ciência e Agrotecnologia, Lavras, v. 32, n. 2, p. 378-384, 2008.
SANTANA, C. T. C.; SANTI, A.; DALLACORT, R.; SANTOS, M. L. Desempenho de cultivares de alface americana em respostas a diferentes doses de torta de filtro. Revista Ciência Agronômica, Fortaleza, v. 43, n. 1, p. 22-29, 2012.

SANTOS, H. G.; JACOMINE, P. K. T.; ANJOS, L. H. C.; OLIVEIRA, V. A.; OLIVEIRA, J. B.; COELHO, M. R.; LUMBRERAS, J. F.; CUNHA, T. J. F. Sistema brasileiro de classificação de solos. Embrapa. 2. ed. Rio de Janeiro: EMBRAPA, 2006. 306 p.

ZUFFO, A. M.; ZUFFO JUNIOR, J. M.; SILVA, L. M. A.; SILVA, R. L.; MENEZES, K. Análise de crescimento em cultivares de alface nas condições do Piauí. Revista Ceres, Viçosa, MG, v. 63, n. 2, p. 145-153, 2016.

WALKENBACH, J. Excel 2010 power programming with VBA. Wiley Publishing Inc, Indianópolis v. 6, 2010. 